\title{
Adsorptive removal of textile reactive dye using Posidonia oceanica (L.) fibrous biomass
}

\author{
${ }^{1,2 *}$ M. C. Ncibi; ${ }^{1,2}$ B. Mahjoub; ${ }^{2}$ M. Seffen \\ ${ }^{1}$ Laboratory of chemistry, High Institute of Agronomy, Chott Meriem 4042, Sousse, Tunisia \\ ${ }^{2}$ Applied Chemistry and Environment Research Unit, EPAM Sousse 4000, Tunisia \\ Received 13 March 2007; revised 20 June 2007; accepted 12 August 2007; available online 1 September 2007
}

\begin{abstract}
The Mediterranean seagrass Posidonia oceanica (L.) leaf sheaths were used as low cost, available and renewable biological adsorbent for the removal of reactive textile dye from aqueous solutions. Batch experiments were carried out for sorption kinetics and isotherms. Operating variables studied were temperature, $\mathrm{pH}$ and chemical pretreatment. Biosorption capacity seems to be enhanced by increasing the temperature. Maximum colour removal was observed at $\mathrm{pH}$ 5. Pre-treating fibres with $\mathrm{H}_{3} \mathrm{PO}_{4}$ and $\mathrm{HNO}_{3}$ solutions increased the adsorption efficiency up to $80 \%$. Experimental sorption kinetic data were fitted to both Lagergren first-order and pseudo-second-order models and the data were found to follow first-order equation for raw fibres and pseudo-second-order for pre-treated ones. Equilibrium data were well represented by the Freundlich isotherm model for all tested adsorption systems. Besides, the thermodynamic study has showed that the dye adsorption phenomenon onto P. oceanica biomass was favourable, endothermic and spontaneous.
\end{abstract}

Key words: Biosorption, posidonia seagrass, reactive dye, chemical treatments, modeling

\section{INTRODUCTION}

Several biological, physical and chemical methods have been used for the treatment of industrial textile wastewater including microbial biodegradation, membrane filtration, oxidation and ozonation (Forgacs, et al., 2004). However, many of these technologies are cost prohibitive, especially when applied for treating large waste streams. Consequently, adsorption techniques seem to have the most potential for future use in industrial wastewater treatment Babel and Opiso, 2007) because of their proven efficiency in the removal of organic and mineral pollutants and for economic considerations (Robinson, et al., 2002a, Garg, et al., 2003, Abdel-Ghani, et al., 2007). The most widely used adsorbent for this purpose is activated carbon, but its overlying coast (McKay, et al., 1987, Low, et al., 1995) has led to search for cheaper alternative materials such as orange and banana peels (Annadurai, et al., 2002), neem leafs (Bhattacharyya, et al., 2003), agricultural residues (Robinson, et al., 2002b) and peanut hull (Gong, et al., 2005). The main objective of the present study was to develop a low cost and efficient wastewater treatment technology by studying the capacities of a

× Corresponding Author Email: ncibi_mc@yahoo.com

Tel.: +21 6733 48546; Fax: +21673348691 marine lignocellulosic material, Posidonia oceanica leaf sheaths for adsorptive removal of a reactive textile dye: C.I. Reactive Red 228. The kinetic and equilibrium data of sorption studies were processed to understand the sorption mechanism of the dye molecule onto $P$. oceanica fibres.

\section{MATERIALS AND METHODS}

Adsorbent and adsorbate preparation

P. oceanica leaf sheaths (PLS) were collected from Chott-Meriem bay (Eastern coast of Tunisia). The fibres are manually separated, washed with generous amounts of distilled water to remove the surface-adhered particles and then dried in an oven at $40^{\circ} \mathrm{C}$ for $48 \mathrm{~h}$ to a constant weight. Two kind of chemical treatments were then performed: $0.2 \mathrm{M}$ nitric acid ( $\mathrm{PLS}-\mathrm{HNO}_{3}$ ) and $0.2 \mathrm{M}$ phosphoric acid (PLS- $\mathrm{H}_{3} \mathrm{PO}_{4}$ ) in one hand and $4^{\circ} \mathrm{CHL}$ sodium hypochlorite (PLS-NaOCl) and $30 \%$ (v/ v) hydrogen peroxide (PLS- $\mathrm{H}_{2} \mathrm{O}_{2}$ ) for a bleaching process in the other hand. For the chemical treatment, a constant mass of $1 \mathrm{~g}$ of dried raw PLS was treated with $200 \mathrm{~mL}$ of the appropriate solution for 6 hours at $25^{\circ} \mathrm{C}$. A Ciba Geigi textile Azo dye has been experimented in this study: C.I. Reactive Red 228 (R. 
Red). Stock solutions were prepared by dissolving accurately weighed amount of dye in distilled water to give a concentration of $1000 \mathrm{mg} / \mathrm{L}$ and diluting when necessary. Initial $\mathrm{pH}$ was adjusted by addition of dilute $\mathrm{HCl}$ or $\mathrm{NaOH}$ solutions.

\section{Batch adsorption experiments}

Adsorption experiments were carried out by agitating $5 \mathrm{~g}$ of PLS with $250 \mathrm{~mL}$ of dye solution for the desired concentration and $\mathrm{pH}$ in a horizontal shaker at $100 \mathrm{rpm}$ for the time required to reach the equilibrium state ( $48 \mathrm{~h})$. Studies were conducted at $25^{\circ} \mathrm{C} \pm 2$ using a temperaturecontrolled water bath. Dye concentration was estimated spectrophotometrically at the wavelength corresponding to maximum absorbance, $540 \mathrm{~nm}$, using a CamSpec M330 spectrophotometer. The samples were taken from the shaker at predetermined time intervals and the dye solution was filtered through a $0.45 \mu \mathrm{m}$ membrane ûlter and then analyzed. The amount of dye adsorbed onto PLS, $q_{e}(\mathrm{mg} / \mathrm{g})$, was calculated as follows:

$$
q_{e^{\prime}}=(C i-C e) \frac{V}{W}
$$

where $C i$ and $C e$ are the initial and equilibrium time solution concentrations of the dye (mg/L), respectively, $V$ the volume of the solution (L) and $W$ the weight of the dry PLS used (g). Each experiment was performed twice at least under identical conditions.

\section{RESULTS}

Effect of temperature

The data of dye adsorption onto raw PLS at different temperatures indicates a change in the dye removal efficiency. This effect is shown in Fig. 1. The increase in the equilibrium sorption capacity of the R. Red dye, for the two concentrations investigated, indicates that a high temperature favours dye removal. Indeed, by increasing the temperature of the reaction from 15 to $60{ }^{\circ} \mathrm{C}$, the equilibrium capacity of the dye increased from 1.092 to $1.824 \mathrm{mg} / \mathrm{g}$ for the concentration of 50 $\mathrm{mg} / \mathrm{L}$ and 2.631 to $3.497 \mathrm{mg} / \mathrm{g}$ for $100 \mathrm{mg} / \mathrm{L}$. Consequently, it is clear that adsorption equilibrium is a thermo-dependent process. This effect may be due to the fact that at higher temperatures, an increase in the movement of the solute occurs. Similar results are mentioned by other researchers (Chakraborty, et al., 2005).

\section{Effect of $p H$ solution}

The initial $\mathrm{pH}$ value of the solution is an important factor which must be considered during sorption studies (Aksu, 2005). The effect of pH on the amount of dye removal was analyzed over the $\mathrm{pH}$ range from 2 to 10 and the results are presented in Fig. 2. As shown, the maximum biosorption capacity was reached at $\mathrm{pH} 5$ with 1.938 and $4.121 \mathrm{mg} / \mathrm{g}$, respectively for 50 and 100 $\mathrm{mg} / \mathrm{L}$ concentration. This trend might be explained by the fact that we deal with an Azo-based reactive dye combining different types of reactive groups. The $\mathrm{pH}$ 5 might correspond to the rate of dissociation of this dye with maximum ionisation of the molecule. Furthermore, in such pH, the PLS combines both negatively and positively charged cells surface, which enhance the electrostatic attraction between anionic and cationic species of both sorbate and adsorbate. Moreover, inhibition of the dye sorption onto raw PLS at low acidic and high basic $\mathrm{pH}$ ranges may be attributed to the increase of hydroxyl and hydrogen ions leading to formation of aqua complexes thereby retarding the dye sorption (Mohan, et al., 2002).

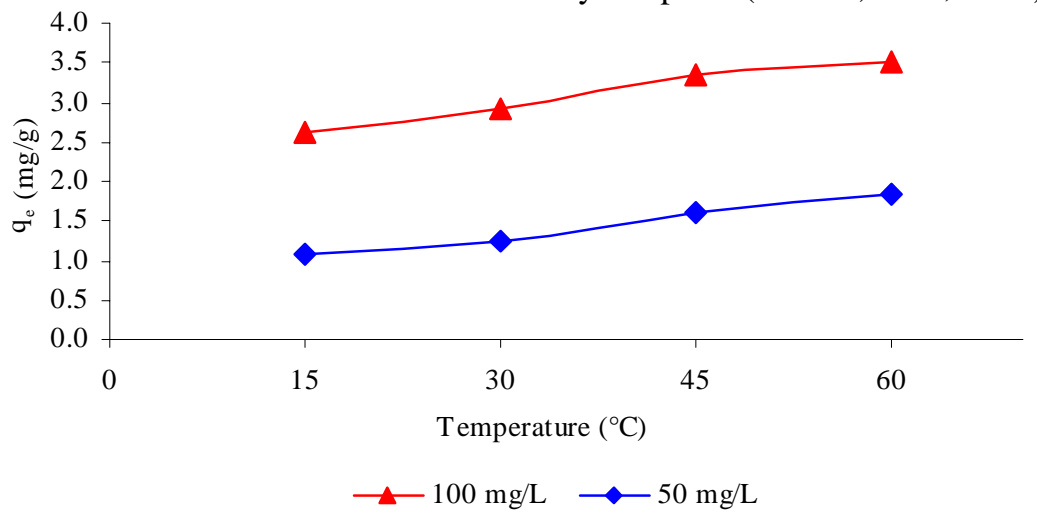

Fig. 1: Influence of temperature on the biosorption equilibrium capacity onto raw PLS $($ Solid/Liquid ratio $=5 \mathrm{~g} / 250 \mathrm{~mL}, \mathrm{pH}=5$, contact time $=48 \mathrm{~h}$, agitation rate $=100 \mathrm{rpm}$ ) 


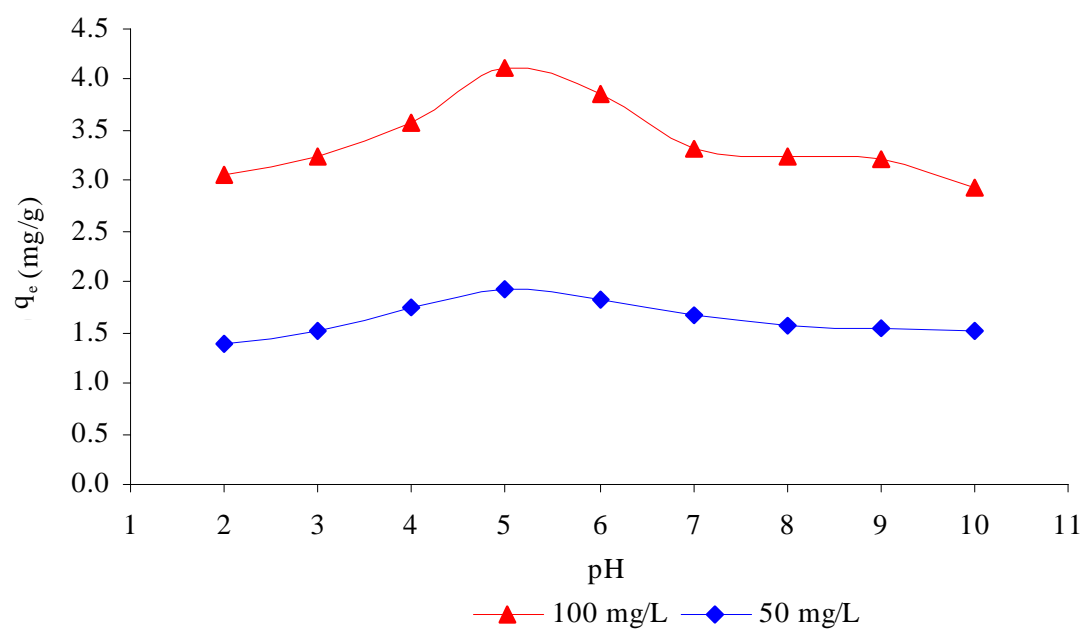

Fig. 2: Influence of $\mathrm{pH}$ on the biosorption equilibrium capacity onto raw PLS $\left(\right.$ Solid $/$ Liquid ratio $=5 \mathrm{~g} / 250 \mathrm{~mL}$, temperature $=25 \pm 2{ }^{\circ} \mathrm{C}$, contact time $=48 \mathrm{~h}$, agitation rate $\left.=100 \mathrm{rpm}\right)$

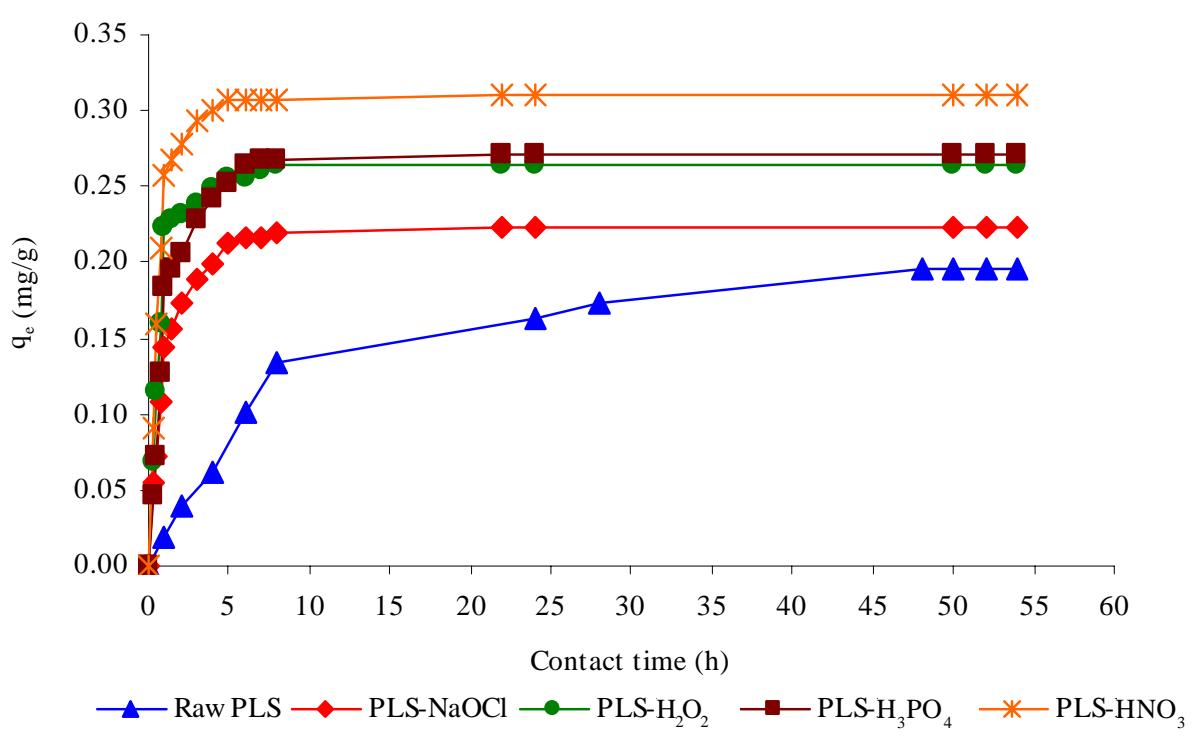

Fig. 3: Biosorption kinetics of R. red onto pretreated PLS

$\left(\right.$ Solid $/$ Liquid ratio $=5 \mathrm{~g} / 250 \mathrm{~mL}, \mathrm{Ci}=10 \mathrm{mg} / \mathrm{L}, \mathrm{pH}=5$, temperature $=25 \pm 2{ }^{\circ} \mathrm{C}$, agitation rate $=100 \mathrm{rpm}$ )

\section{Effect of chemical pre-treatment}

Fig. 3 shows that all chemical treatment had enhanced the biosorption equilibrium capacity compared with the raw PLS. Indeed, for an initial dye concentration equal to $10 \mathrm{mg} / \mathrm{L}, \mathrm{PLS}-\mathrm{HNO}_{3}$ had the highest removal amount (0.310 mg/g). PLS- $\mathrm{H}_{3} \mathrm{PO}_{4}, \mathrm{PLS}-\mathrm{H}_{2} \mathrm{O}_{2}$ and PLS-NaOCl had also showed an increase in dye uptake with 0.271, 0.265 and $0.222 \mathrm{mg} / \mathrm{g}$, respectively. In addition, the equilibrium was reached within $10 \mathrm{~h}$ for all pre-treated PLS, against $48 \mathrm{~h}$ for the raw PLS. In the case of PLS treated with acidic solutions, it seems that the negative charges on the hydrolysed $\mathrm{R}$. red dye molecules were electrostatically attracted by the positive charge on the surface of PLS- $\mathrm{HNO}_{3}$ and $\mathrm{PLS}-\mathrm{H}_{3} \mathrm{PO}_{4}$, which was increased by the excess of $\mathrm{H}^{+}$ions in the solution (Kumar, et al., 2002). Therefore, such results suggest that the present biosorption phenomenon might be via a chemiosorption mechanism. In other hand, the increase of the dye uptake using bleached PLS is probably due to the hydrolysis of the natural pigments (mainly phycoxanthines) which are chemically similar to synthetic 
dyes, generating therefore new active sorptive sites. The enhancement of the dye adsorption capacity through chemical treatment of the biomass was also reported by Inthorn, et al. (2004) and Gong, et al. (2005).

\section{Sorption kinetic modelling}

For evaluating the adsorption kinetics of R. Red dye, Lagergren ûrst-order and pseudo second order models were used to ût the experimental data. The first order equation is:

$$
\log \left(q_{e^{-q}}\right)=\log q_{e}-\frac{K_{a d}}{2.303} t
$$

where $q_{e}$ and $q$ (both in $\mathrm{mg} / \mathrm{g}$ ) are the amounts of adsorbed dye respectively at equilibrium time and at time $t$. $K_{a d}\left(\mathrm{~h}^{-1}\right)$ is the rate constant of first order model. From the slopes and intercepts of plots of $\log \left(q_{e}-q\right)$ versus $t$ obtained for the biosorption of R. Red by PLS$\mathrm{HNO}_{3}$, PLS-NaOCl and raw PLS (Fig. 4), the first order rate constant $K_{a d}$ and the calculated $q_{e}\left(q_{\text {ecal }}\right)$ values were determined, respectively (Table 1 ). The correlation coefficients for the first-order kinetic model obtained at all studied PLS were low, except for the raw biomass with $99.09 \%$. However, in the same, the theoretical $q_{\text {ecal }}$ did not give acceptable values even for the raw PLS. Therefore, these studied biosorption systems were not considered as a first order reaction, and its applicability is just over the initial 20 min of the sorption process involving raw PLS. This time-limited application of the
Lagergren model was previously mentioned in the scientific literature by Namasivayam, et al. (1996) and Aksu and Donmez (2003). In the order hand, the pseudosecond-order model is also based on the biosorption capacity of the solid phase. But, contrary to the previous model it predicts the sorption behaviour over the whole time adsorption (Ho and McKay, 1999a). The pseudo second order equation is expressed as:

$$
\frac{t}{q}=\frac{1}{K_{2} \cdot q_{e}{ }^{2}}+\frac{t}{q_{e}}
$$

where $K_{2}$ is the rate constant of second-order model (g/mg.h). When the second-order kinetic is applicable, the plot of $t / q$ against $t$ should give a linear relationship (Fig. 5), from which $K_{2}$ and $q_{\text {ecal }}$ can be determined respectively from the intercept and slope of the plot. The results are given in Table 1 . The second-order model shows satisfactory fit with the experimental data related to the biosorption onto treated PLS with high correlation coefficients (99.9\%). Moreover, as shown in Table 1 , the calculat $q_{e}$ are quite similar to the experimental values. However; for the case of raw PLS, the second-order model did not correlates well based on both low correlation coefficient and unacceptable value of the $q_{\text {ecal }}$. Hence, as the pseudo-second order kinetic model provide the best correlation of the experimental data using treated biomass, chemical reaction might be considered as the rate-controlling step in the studied adsorption systems (Ho and McKay, 1999b).

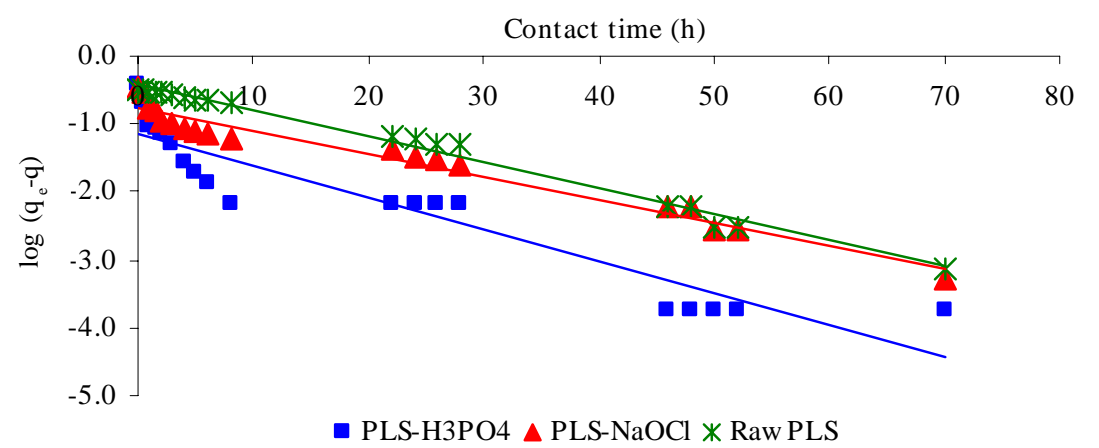

Fig. 4: Linearized lagergren first-order kinetic model for R. red uptake by raw and treated PLS $\left(\right.$ Solid/Liquid ratio $=5 \mathrm{~g} / 250 \mathrm{~mL}, \mathrm{Ci}=10 \mathrm{mg} / \mathrm{L}, \mathrm{pH}=5$, temperature $=25 \pm 2{ }^{\circ} \mathrm{C}$ )

\begin{tabular}{|c|c|c|c|c|c|c|c|}
\hline & \multirow[b]{2}{*}{$\begin{array}{l}\mathrm{q}_{\mathrm{e} \exp } \\
(\mathrm{mg} / \mathrm{g})\end{array}$} & \multicolumn{3}{|c|}{$\begin{array}{l}\text { Lagergren first-order model } \\
\end{array}$} & \multicolumn{3}{|c|}{ Pseudo-second-order model } \\
\hline & & $\begin{array}{l}\mathrm{K}_{\mathrm{ad}} \\
\left(\mathrm{h}^{-1}\right)\end{array}$ & $\begin{array}{l}\text { qecal } \\
(\mathrm{mg} / \mathrm{g})\end{array}$ & $\mathrm{R}^{2}$ & $\begin{array}{l}\mathrm{K}_{2} \times 10^{-2} \\
\text { (g/mg.h) }\end{array}$ & $\begin{array}{l}\text { qe cal } \\
\text { (mg/g) }\end{array}$ & $\mathrm{R}^{2}$ \\
\hline Raw PLS & 0.320 & 0.0875 & 0.348 & 0.990 & 0.79 & 0.418 & 0.953 \\
\hline PLS- $\mathrm{H}_{3} \mathrm{PO}_{4}$ & 0.376 & 0.1004 & 0.307 & 0.876 & 35.43 & 0.377 & 0.999 \\
\hline PLS-NaOCl & 0.359 & 0.0783 & 0.467 & 0.967 & 8.74 & 0.364 & 0.999 \\
\hline
\end{tabular}

Table 1: Adsorption rate constants calculated from Lagergren first order and pseudo secondorder kinetic models 


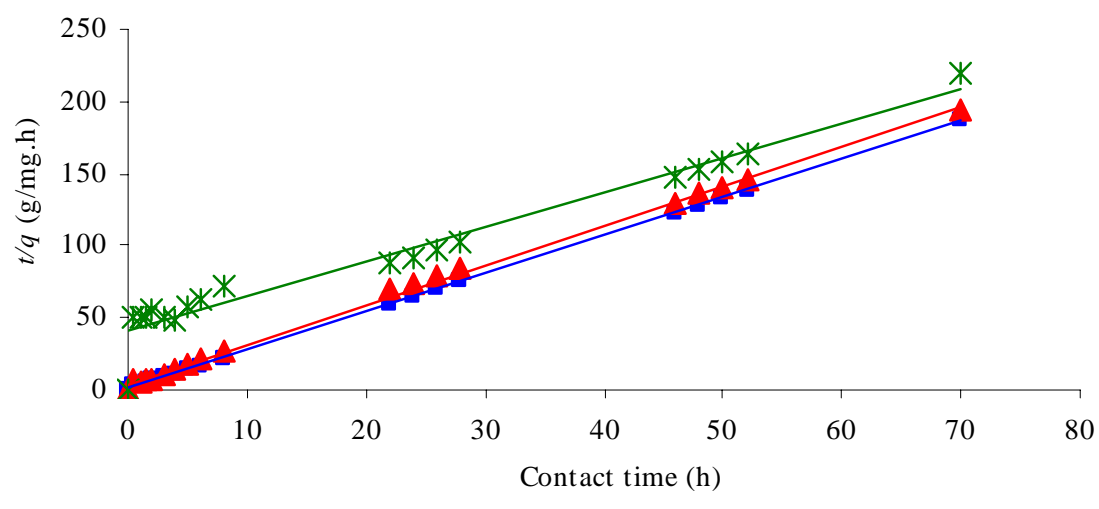

- PLS-H3PO4 $\triangle$ PLS-NaOCl $*$ Raw PLS

Fig. 5: Linearized pseudo second order kinetic model for R. red uptake by raw and treated PLS $\left(\right.$ Solid/Liquid ratio $=5 \mathrm{~g} / 250 \mathrm{~mL}, \mathrm{Ci}=10 \mathrm{mg} / \mathrm{L}, \mathrm{pH}=5$, temperature $=25 \pm 2{ }^{\circ} \mathrm{C}$ )

\section{Sorption equilibrium modelling}

The adsorption curves were applied to both Langmuir and Freundlich equations. The linearized form of the Langmuir isotherm equation is represented as:

$$
\frac{C e}{q_{e}}=\frac{1}{K_{L} \cdot q^{0}}+\frac{C e}{q^{0}}
$$

where $q_{e}(\mathrm{mg} / \mathrm{g})$ is the amount adsorbed per unit mass of biosorbent corresponding to complete coverage of the adsorptive sites, $\mathrm{Ce}(\mathrm{mg} / \mathrm{L})$ is the equilibrium concentration of dye in solution, $q^{\circ}(\mathrm{mg} / \mathrm{g})$ is the monolayer sorption capacity of the biomass and the Langmuir constant $K_{L}(\mathrm{~L} / \mathrm{mg})$ is the sorption energy. A plot of $C e / q_{e}$ versus $C e$ would give $q^{\circ}$ and $K_{L}$ from the slope and intercept, respectively. The linearized form of the Freundlich isotherm equation is given by:

$$
\log q_{e}=\log K_{F}+\frac{1}{n} \log C e
$$

where $K F\left((\mathrm{mg} / \mathrm{g})^{*}(\mathrm{~L} / \mathrm{mg})^{\mathrm{n}}\right)$ is the Freundlich constant and $n$ the constant related to adsorption intensity. A plot of $\ln q_{e}$ against $\ln C e$ would give the value of $n$ and $K_{F}$, from the slope and the intercept, respectively. The results of both Langmuir and Freundlich adsorption constants at different $\mathrm{pH}$ values were shown in Table 2. Fig. 6 shows the fitted equilibrium data for both isotherm models. The low correlation coefficient related to the Langmuir isotherm showed that this model is not suitable to describe the adsorption equilibrium, except for $\mathrm{pH} 5\left(\mathrm{R}^{2}=96.8 \%\right)$ which probably predicts the monolayer coverage of $\mathrm{R}$. Red onto raw PLS. In the other hand, the Freundlich isotherms generate a satisfactory fit to experimental data for all tested $\mathrm{pH}$ with high correlation values (99.2$99.5 \%)$. Moreover, it is apparent that value of the constant, $n$ obtained indicates favourable adsorption, as it lies between 1 and 10 . On the other hand, in order to situate our novel biosorbent among those used to remove synthetic Azo dyes from aqueous solutions, a comparison based on both Langmuir saturation capacity $q^{\circ}$ and Freundlich adsorption intensity $n$ was made.

\section{Thermodynamic studies}

In order to qualify the present adsorptive removal process, thermodynamic factors including the Gibbs free energy change of adsorption, " $\mathrm{G}^{\circ}(\mathrm{kJ} / \mathrm{mol})$, the enthalpy change of adsorption, " $\mathrm{H}^{\circ}(\mathrm{kJ} / \mathrm{mol})$ and the entropy change of adsorption; " $\mathrm{S}^{\circ}(\mathrm{J} / \mathrm{mol} / \mathrm{K})$ were calculated using the following equations (6-8).

$$
\begin{aligned}
& K d=\frac{q_{e}}{C e} \\
& \Delta G^{0}=-R T . \operatorname{Ln}(K d) \\
& \operatorname{Ln}(K d)=\frac{\Delta H^{0}}{R T}+\frac{\Delta S^{0}}{R}
\end{aligned}
$$

where $K d$ is the adsorption distribution coefficient, $R$ is the universal gas constant $(8.314 \mathrm{KJ} / \mathrm{mol} / \mathrm{K})$ and $T$ is the absolute temperature (K). The experimented temperature range was from 15 to $60^{\circ} \mathrm{C}$. The Gibbs free energy indicates the degree of spontaneity of the sorption process and the higher negative value reflects more energetically favourable sorption. (" $\mathrm{H}^{\circ}$ ) and (" $\mathrm{G}^{\circ}$ ) values, recorded in Table 4, were obtained from the slope and intercept of a plot of $L n K d$ against 1/T. 
M. C. Ncibi, et al.

Table 2: Langmuir and Freundlich isotherms constants related to the biosorption of R. red onto raw PLS at different pH solution

\begin{tabular}{llllll}
\hline & \multicolumn{2}{l}{ Langmuir constants } & & \multicolumn{2}{c}{ Freundlich constants } \\
& $\mathrm{q}^{\circ}$ & $\mathrm{K}_{\mathrm{L}}$ & $\mathrm{R}^{2}$ & $\mathrm{~K}_{\mathrm{F}}$ & $\mathrm{n}$ \\
\hline pH 3 & 16.67 & 0.01 & 0.598 & 0.13 & 1.13 \\
pH 5 & 5.74 & 0.07 & 0.968 & 0.53 & 0.995 \\
pH 7 & 16.75 & 0.01 & 0.604 & 0.11 & 0.992 \\
\hline
\end{tabular}

Table 3: Comparison of adsorption isotherm characteristics between $P$. oceanica fibres and other studied sorbents for textile Azo dye removal

\begin{tabular}{lllllll}
\hline Sorbents & Textile dyes & $\mathrm{pH}$ & $\mathrm{T}\left({ }^{\circ} \mathrm{C}\right)$ & $\begin{array}{l}\text { Langmuir } \\
q^{\circ}(\mathrm{mg} / \mathrm{g})\end{array}$ & Freundlich $n$ & References \\
\hline Posidonia oceanica & Reactive red 228 & 5 & 30 & 5.74 & 1.65 & This study \\
Orange peel & Procion orange & 5.2 & 29 & 1.33 & 2.07 & Namasivayam, et al., 1996 \\
Apple pomace & 5 Reactive dyes & 7.2 & 20 & 2.79 & 0.51 & Robinson, et al., 2002a \\
Activated sludge & Reactive blue 2 & 2 & 25 & $\mathrm{NA}$ & 1.16 & Aksu, 2001 \\
Pichia carsonii & Reactive blue 19 & 3 & 28 & 5 & $\mathrm{NA}$ & Polman and Breckenridge, 1996 \\
Kluyveromyces marxianus & Cibacron orange & 3 & 25 & 8.5 & $\mathrm{NA}$ & Bustard, et al., 1998 \\
Rice husk & Bismarck brown & NA & 27 & 84.4 & 1.95 & (Kumar and Sivanesan, 2005 \\
Pseudomonas luteola & Reactive violet 2 & 3 & 28 & 96.4 & $\mathrm{NA}$ & Hu, 1996 \\
\hline NA: Not available & & & & & &
\end{tabular}

Table 4: Thermodynamic parameters for adsorption of R. red onto P. oceanica fibres

\begin{tabular}{|c|c|c|c|c|c|}
\hline \multicolumn{4}{|c|}{$\triangle \mathrm{G}^{\circ}(\mathrm{kJ} / \mathrm{mol})$} & \multirow{2}{*}{$\begin{array}{l}\triangle \mathrm{H}^{\circ} \\
(\mathrm{kcal} / \mathrm{J})\end{array}$} & \multirow{2}{*}{$\frac{\triangle \mathrm{S}^{\circ}}{(\mathrm{J} / \mathrm{mol} / \mathrm{K})}$} \\
\hline $15^{\circ} \mathrm{C}$ & $30{ }^{\circ} \mathrm{C}$ & $45^{\circ} \mathrm{C}$ & $60^{\circ} \mathrm{C}$ & & \\
\hline-7.08 & -6.88 & -6.30 & -5.69 & 67.34 & -129.81 \\
\hline
\end{tabular}
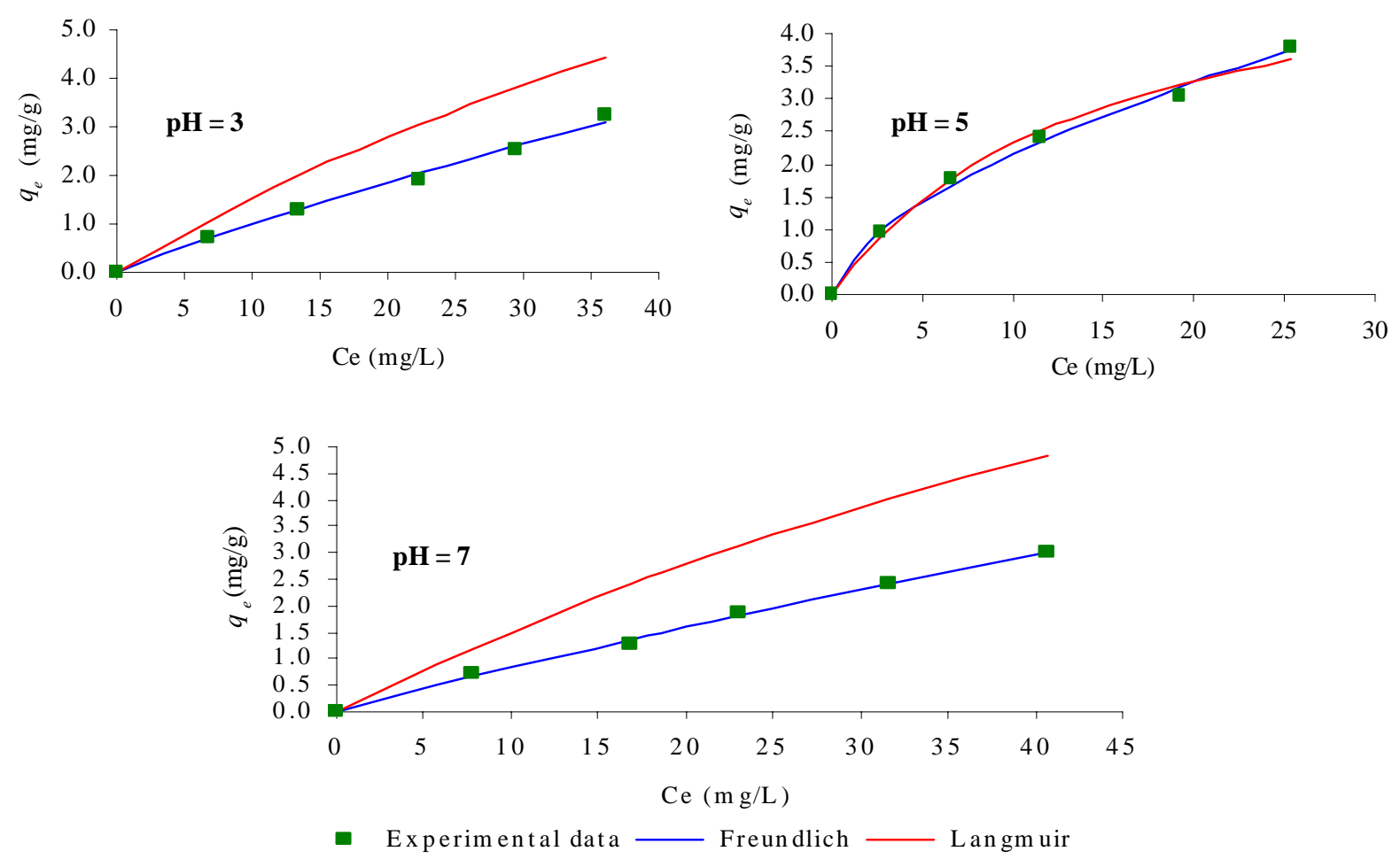

Fig. 6: Adsorption isotherms modelling of R. red on raw PLS at different $\mathrm{pH}$ $\left(\right.$ Solid $/ \mathrm{Liquid}$ ratio $=5 \mathrm{~g} / 250 \mathrm{~mL}$, contact time $=48 \mathrm{~h}$, temperature $=25 \pm 2{ }^{\circ} \mathrm{C}$, agitation rate $\left.=100 \mathrm{rpm}\right)$ 


\section{DISCUSSION AND CONCLUSION}

In this work, the biosorption process of the reactive textile dye (C.I. Reactive Red 228) have been examined onto Posidonia oceanica (L.) leaf sheaths fibres. It was shown that adsorption equilibrium capacity was enhanced by raising the temperature up to $60^{\circ} \mathrm{C}$. This may be due to a relative increase in the tendency of dye molecules to escape from the liquid phase to the solid phase with increasing temperature of the solution (Ho and McKay, 2003). Besides, the highest dye removal efficiency was found at $\mathrm{pH} 5$ which might correspond to the rate of dissociation of the studied dye with maximum ionisation of the molecule. Furthermore, all chemically treated PLS had showed enhancement in dye removal and they had also reached the equilibrium state quicker than raw PLS. Such tendency was related to the protonation of the biomass surface for acidic attacks and the hydrolysis of the inner pigments for bleaching treatments. On the other hand, Kinetic rate constants were determined and the data fit well with Lagergren first-order using raw PLS and pseudo second order model for treated PLS. As well, adsorption parameters for Langmuir and Freundlich isotherms were determined at different $\mathrm{pH}$ and the equilibrium data fit well with the Freundlich model at all experimented $\mathrm{pH}$. Dealing with the comparative study, the related results (Cf. Table 3 ) revealed that the $P$. oceanica fibres could be considered as a promising biomaterial to remove textile dyes when compared to orange peels (Namasivayam, et al., 1996), apple pomace (Robinson, et al., 2002a), dried activated sludge (Aksu, 2001) and Pichia carsonii (Polman and Breckenridge, 1996). However, other sorbents have shown higher dye removal capacities among them Kluyveromyces marxianus (Bustard, et al., 1998), rice husk (Kumar and Sivanesan, 2005) and Pseudomonas luteola (Hu, 1996). In addition, according to the thermodynamic analysis, the negative values of (" $G^{\circ}$ ) indicate the spontaneous nature of the adsorption process for both dyes. Besides, the positive values of (" $\left.\mathrm{H}^{\circ}\right)$ indicate that the sorption process was endothermic and the negative values of (" $\mathrm{S}^{\circ}$ ) suggest the probability of favourable adsorption (Smith and Van Ness, 1987). Therefore, in addition to its phenol and methylene blue removal capacities (Ncibi, et al., 2006 and 2007), the $P$. oceanica leaf sheaths could be considered as a promising material to be used as an efficient and low cost material for dye removal by biosorption. Currently, a study on the immobilization of some fungi or bacteria onto the Posidonia fibres is in progress in order to optimize the dye uptake capacity.

\section{ACKNOWLEDGEMENTS}

The authors thank the Tunisian Ministry of Defence for financial support and the Ministry of Scientific Research, Technology and Competency Development for its technical assistance.

\section{REFERENCES}

Abdel-Ghani, N.T.; Hefny, M.; El-Chaghaby, G.A.F., (2006). Removal of lead from aqueous solution using low cost abundantly available adsorbents. Int. J. Environ. Sci. Tech., 4 (1), 67-73.

Aksu, Z.; Donmez, G., (2003). A comparative study on the biosorption characteristics of some yeasts for Remazol Blue reactive dye. Chemosphere, 50, 1075-1083.

Aksu, Z., (2001). Biosorption of reactive dues by dried activated sludge: equilibrium and kinetic modelling. Biochem. Eng. J., 7, 9-84.

Aksu, Z., (2005). Application of biosorption for the removal of organic pollutants: a review. Process Biochem., 40, 9971026.

Annadurai,G.; Juang, R.; Lee, D., (2002). Use of cellulosebased wastes for adsorption of dyes from aqueous solutions. J. Hazard. Mater. B92, 263-274.

Babel, S.; Opiso, M.E., (2007). Removal of Cr from synthetic wastewater by sorption into volcanic ash soil. Int. J. Environ. Sci. Tech., 4 (1), 99-107.

Bhattacharyya, K.G.; Sarma, A., (2003). Adsorption characteristics of the dye, brilliant green, on neem leaf powder. Dyes Pigments, 57, 211-222.

Bustard, M.; McMullan, G.; McHale, A.P., (1998). Biosorption of textile dyes by biomass derived from Kluveromyces marxianus IMB3. Bioprocess Eng., 19, 427-430.

Chakraborty, S.; De, S.; DasGupta, S.; Basu, J.K., (2005). Adsorption study for the removal of a basic dye: experimental and modelling. Chemosphere, 58, 10791086.

Forgacs, E.; Cserhatia, T.; Oros, G., (2004). Removal of synthetic dyes from wastewaters: a review. Environ. Int., 30, 953-971.

Garg, V.K.; Gupta, R.; Yadav, A.B.; Kumar, R., (2003). Dye removal from aqueous solution by adsorption on treated sawdust. Bioresour. Tech., 89, 121-124.

Gong, R.M.; Ding, Y.; Li, M.; Yang, C.; Liu, H.J.; Sun, Y.Z., (2005). Utilization of powdered peanut hull as biosorbent for removal of anionic dyes from aqueous solution. Dyes Pigments, 64, 187-192.

Ho, Y.S.; McKay, G., (1999a). A kinetic study of dye sorption by biosorbent waste product pith. Resour. Conserv. Recycl., 25, 171-193.

Ho, Y.S.; McKay, G., (1999b). Pseudo-second order model for sorption processes. Process Biochem. 34, 451-465.

Ho, Y.S.; McKay, G., (2003). Sorption of dyes and copper ions onto biosorbents. Process Biochem. 38, 1047-1061.

Hu, T.L., (1996). Removal of reactive dyes from aqueous solution by different bacterial genera. Water Sci. Tech., 34, 89-95.

Inthorn, D.; Singhtho, S.; Thiravetyan, P.; Khan, E., (2004). Decolorization of basic, direct and reactive dyes by pretreated narrow-leaved cattail (Typha angustifolia Linn.). Bioresour. Tech., 94, 299-306. 
Kumar, V.; Yang, T., (2002). $\mathrm{HNO}_{3} / \mathrm{H}_{3} \mathrm{PO}_{4}-\mathrm{NAO}_{2}$ mediated oxidation of cellulose preparation and characterization of bioabsorbable oxidized celluloses in high yields and with different levels of oxidation. Carbohyd. Polym., 48, 403412.

Kumar, V.K.; Sivanesan, S., (2005). Prediction of optimum sorption isotherm: Comparison of linear and non-linear method. J. Hazard. Mater., B126, 198-201.

Low, K.S.; Lee, C.K.; Tan, K.K., (1995). Biosorption of basic dye by water hyacinth roots. Bioresour. Tech., 52, 79-83.

McKay, G.; Ramprasad, G.; Mowli, P., (1987). Desorption and regeneration of dye colours from low-cost materials. Water Res., 21, 375-377.

Mohan, S.V.; Rao, N.C.; Karthikeyan, J., (2002). Adsorptive removal of direct azo dye from aqueous phase onto coal based sorbents: a kinetic and mechanistic study. J. Hazard. Mater., B90, 189-204.

Namasivayam, C.; Muniasamy, N.; Gayatri, K.; Rani, M.; Ranganathan, K., (1996). Removal of dyes from aqueous solutions by cellulosic waste orange peel. Bioresour. Tech., 57, 37-43.
Ncibi, M.C.; Mahjoub, B.; Seffen, M., (2006). Biosorption of phenol onto Posidonia oceanica (L.) seagrass in batch system: Equilibrium and kinetic modelling. Can. J. Chem. Eng., 84, 495-500.

Ncibi, M.C.; Mahjoub, B.; Seffen, M., (2007). Kinetic and equilibrium studies of methylene blue biosorption by Posidonia oceanica (L.) fibres. J. Hazard. Mater., B139, 280-285.

Polman, J.K.; Breckenridge, C.R., (1996). biomass-mediated binding and recovery of textile dyes from waste effluents. Text. Chem. Color, 28, 31-35.

Robinson, T.; Chandran, B.; Nigam, P., (2002a). Removal of dyes from a synthetic textile dye effluent by biosorption on apple pomace and wheat straw. Water Res., 36, 2824-2830.

Robinson, T.; Chandran, B.; Nigam, P., (2002b). Effect of pretreatments of three waste residues, wheat straw, corncobs and barley husks on dye adsorption. Bioresour. Tech., 85, 119-124.

Smith, J.M.; Van Ness, H.C., (1987). Introduction to chemical engineering thermodynamics. Fourth edition, McGraw-Hill, Singapore.

\section{AUTHOR (S) BIOSKETCHES}

Ncibi, M. C., is a Ph.D. student in plant protection and Environment at the High Institute of Agronomy of Chott Meriem, Tunisia. Researcher in the Applied Chemistry and Environment Research Unit at the Military Academy of Sousse, Tunisia. Email: ncibi_mc@yahoo.com

Mahjoub, B., Ph.D., is assistant professor of chemistry at the High Institute of Agronomy of Chott Meriem, Tunisia. Researcher in the "Applied Chemistry and Environment Research Unit" at the Military Academy of Sousse, Tunisia. Email: bomahjoub@yahoo.fr

Seffen, M., Ph.D., is professor of chemistry at the Military Academy of Sousse, Tunisia. Chief of the “Applied Chemistry and Environment” Research Unit. Email: mongiseffen@yahoo.fr

This article should be referenced as follows:

Ncibi, M.C.; Mahjoub, B.; Seffen, M., (2007). Adsorptive removal of textile reactive dye using Posidonia oceanica (L.) fibrous biomass. Int. J. Environ. Sci. Tech., 4 (4), 433-440. 